\title{
REVIEW
}

\section{Cyclin-Dependent Kinase Inhibitors and the Treatment of Gastrointestinal Cancers}

\author{
Sameh Mikhail, * Christopher Albanese, ${ }^{\dagger \dagger}$ and Michael J. Pishvaian \\ From the James Cancer Hospital and Solove Research Institute,* The Ohio State University Comprehensive Cancer Center, Columbus, Ohio; and the \\ Lombardi Comprehensive Cancer Center ${ }^{\dagger}$ and the Department of Pathology, ${ }^{\ddagger}$ Georgetown University Medical Center, Washington, District of Columbia
}

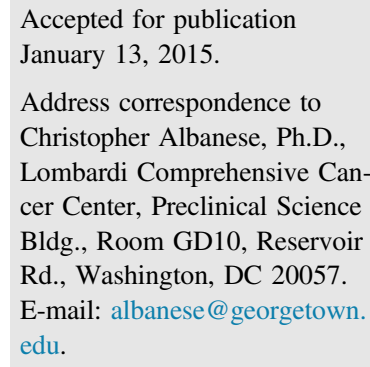

Unrestrained proliferation is a hallmark feature of gastrointestinal (GI) cancers. ${ }^{1}$ The molecular pathogenesis of GI cancers is linked to oncogene activation such as RAS, dysfunction of tumor suppressor genes such as adenomatous polyposis coli, alternations in DNA repair pathways such as mismatch repair gene abnormalities, and cell-cycle dysregulation such as cyclin-dependent kinase (CDK) 4 overexpression. ${ }^{1-3}$ Other events that play integral roles in the development of GI cancers include inflammation and immune dysregulation, and the interaction of these causative factors was recently reviewed. ${ }^{3}$ Given the prevalence of cellcycle abnormalities in GI cancers, there is growing interest in developing and testing inhibitors that target the cell cycle. ${ }^{1}$

\section{Overview of the Mammalian Cell Cycle}

The cell cycle is a highly structured and regulated system, composing of multiple regulatory, catalytic, and inhibitory proteins that act to direct normal mammalian cell proliferation and differentiation. It is not surprising, therefore, that the mechanisms that control normal cell division are frequently altered in many diseases, and aberrant cell-cycle control is a hallmark of most cancers. ${ }^{4}$ Cell division is divided into two distinct stages, mitosis (M), in which the cell prepares for and undergoes cell division, ${ }^{5}$ and interphase, which is further divided into three subphases, $G_{1}, S$, and $\mathrm{G}_{2}$ (Figure 1). All phases of the cell cycle are controlled primarily through the cyclic expression of the regulatory cyclins and their catalytic partners, the CDKs, and inhibited by the CDK inhibitors (CDKis). ${ }^{4,6}$ At least nine CDKs are

\footnotetext{
Supported by a Georgetown-Howard Universities Center for Clinical and Translational Science Pilot and Collaborative Program Clinical and Translational Science Award, US Department of Defense grant W81XWH13-1-0327, and NIH grants R21 CA182050 and P30 CA51008-18 (Weiner) (C.A.).

Disclosures: None declared.
} 


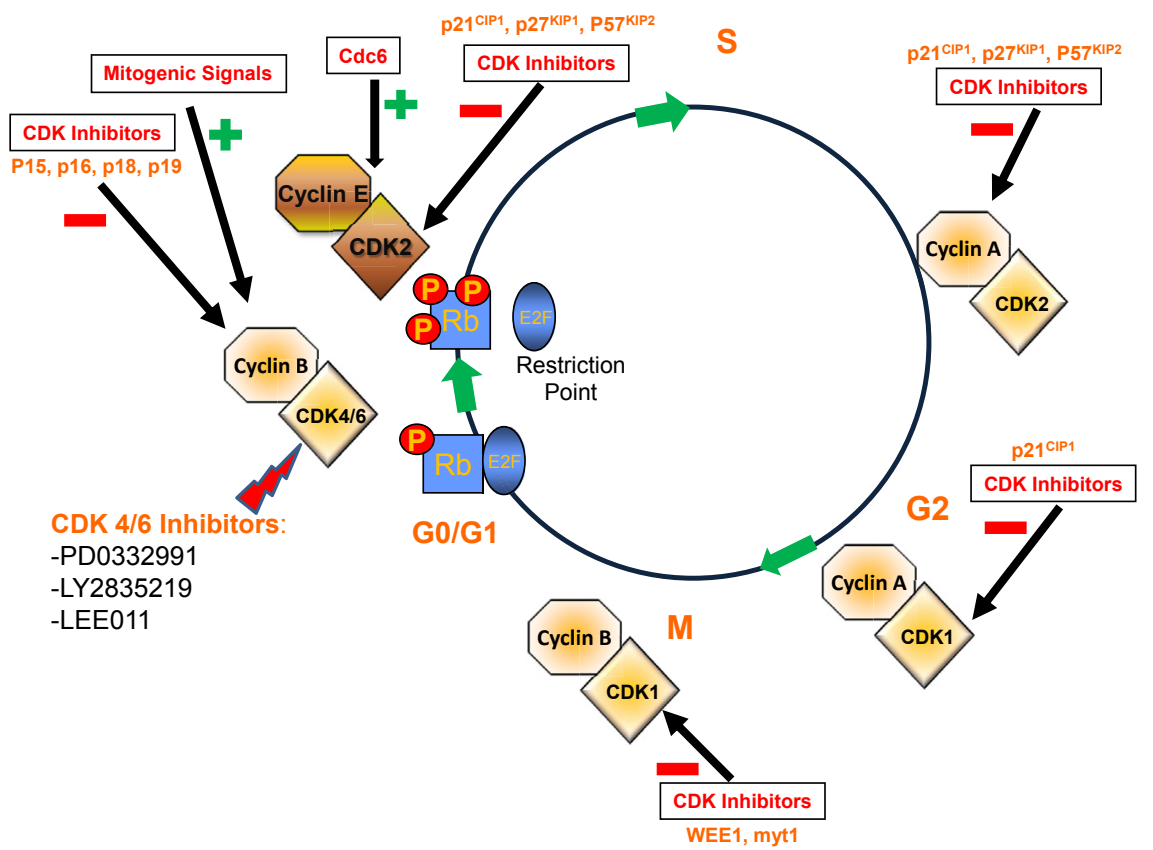

Figure 1 Key regulators of the mammalian cell cycle. The green plus signs represent positive regulators of cell cycle progression, whereas the red minus sign are cell cycle inhibitory proteins. The yellow $P$ represent phosphorylation events on the $\mathrm{Rb}$. Also shown are three CDK4/6 inhibitors that are currently in various stages of clinical development: PD-033299 (Pfizer, New York, NY), LY2835219 (Eli Lilly, Indianapolis, IN), and LEE011 (Novartis, Basel, Switzerland). CDK, cyclindependent kinase; $\mathrm{Rb}$, retinoblastoma protein. described, although only five of them have defined roles in the cell cycle ${ }^{6}$ (Table 1). CDK4/6 associates with the D-type cyclins (D1, D2, and D3) to regulate cell-cycle progression in the $G_{1}$ phase. ${ }^{4,6}$ Similarly, the cyclin E/CDK2 complex regulates the late $G_{1}$ phase and the induction of DNA synthesis in early S phase. CDK2 also associates with cyclin A to control proper DNA replication and synthesis in the $\mathrm{S}$ phase. ${ }^{7}$ As the cell-cycle progresses, cyclin A then associates with CDK1 to promote cell entry into the $\mathrm{M}$ phase. This function is also aided by the activity of CDK7 and cyclin $\mathrm{H}$. CDKis include several families that differ on the basis of their structure and target. ${ }^{8}$ Finally, CDK1 and cyclin B function as the key mediators of mitotic entry. ${ }^{8}$

\section{The Cell Cycle}

The $G_{1}$ or Gap 1 phase was originally described as the period of time that occurred before the onset of DNA synthesis (the $\mathrm{S}$ phase). ${ }^{9}$ Normal cells deprived of the proper growth conditions arrest in a resting or $\mathrm{G}_{0}$ part of $\mathrm{G}_{1}{ }^{7}$ On stimulation by mitogenic signals, these quiescent cells begin to progress toward a major $G_{1}$ checkpoint termed the restriction $(\mathrm{R})$ point in $\mathrm{G}_{1}$. The $\mathrm{R}$ point is regulated by the retinoblastoma $1(R b l)$ tumor suppressor gene. In its hypophosphorylated state $\mathrm{Rb}$ binds to members of the $\mathrm{E} 2 \mathrm{~F}$ family of transcription factors, most notably E2F1. ${ }^{7}$ This $\mathrm{Rb} / \mathrm{E} 2 \mathrm{~F}$ interaction suppresses transcription of critical E2Fregulated cell-cycle genes through the recruitment of chromatin remodeling enzymes such as histone deacetylases. ${ }^{10}$

Early $G_{1}$ progression is controlled by the D-family of cyclins and their catalytic protein partners, CDK4 or CDK6. Cyclin D (CCND1) gene expression and protein amounts are low in quiescent cells and are rapidly induced on stimulation by growth-supportive conditions or through the activity of many oncogenes. ${ }^{7}$ Cyclin D then dimerizes with CDK4 or CDK6 to form a catalytically active protein complex. One of the major substrates for the cyclin D/CDK4 or CDK6 complex is $\mathrm{Rb}$. The phosphorylation of $\mathrm{Rb}$ by the cyclin $\mathrm{D} / \mathrm{CDK}$ complex begins the stochastic inactivation of $\mathrm{Rb}$ and allows the cell cycle to progress toward the $\mathrm{R}$ point of the cell cycle. Once past the $\mathrm{R}$ point, cells become committed to entering the $\mathrm{S}$ phase. The inactivation of $\mathrm{Rb}$ relieves its inhibitory action on the transcription factor E2F, which thereby supports further progression through the cell cycle. ${ }^{7} \mathrm{E} 2 \mathrm{~F}$ directs the synthesis of cyclin E and CDK2 which further inactivates $\mathrm{Rb}$. It is now evident that $\mathrm{E} 2 \mathrm{~F}$ regulates the expression of a variety of genes that mediate DNA replication, nucleotide biosynthesis, and DNA repair activities such as DNA polymerase $\alpha$, thymidine kinase, thymidylate synthase, ribonucleotide reductase, and RAD51.

To maintain proper early $\mathrm{G}_{1}$ regulation, the activity of the cyclin D1/CDK4 or CDK6 complex is antagonized by members of the INK4 family of CDKis. The INK4 family is composed of $\mathrm{p} 16^{\mathrm{INK} 4 \mathrm{a}}, \mathrm{p} 15^{\mathrm{INK} 4 \mathrm{~b}}, \mathrm{p} 18^{\mathrm{INK} 4 \mathrm{c}}$, and $\mathrm{p} 19^{\mathrm{INK} 4 \mathrm{~d}}$, which specifically inhibit the catalytic subunits of CDK4 and CDK6. ${ }^{9}$ Similarly, the CDK interacting protein/kinase inhibitory protein (CIP/KIP) family of CDKis (p21 ${ }^{\mathrm{Cip} 1}$, $\mathrm{p} 27^{\mathrm{Kip} 1}$, and $\mathrm{p} 57^{\mathrm{Kip}}$ ) are potent inhibitors of the $\mathrm{E}$ - and A-type cyclins and their catalytic partners, CDK2 and CDK1, and to a lesser extent of the CDK1/cyclin B complex in $\mathrm{G}_{2}{ }^{3,8}$ Progression through late $\mathrm{G}_{1}$ and the induction of DNA synthesis in $\mathrm{S}$ phase are induced by the increased cyclin $\mathrm{E}$ protein amounts, and the resultant association with $\mathrm{CDK} 2$, the primary catalytic partner of cyclin E. The activity of the cyclin E/CDK2 complex is potentiated by 
Table 1 Cyclins, CDKs, and Their Inhibitors

\begin{tabular}{|c|c|c|}
\hline Cell-cycle phase & Cyclins and CDKs & CDK inhibitors (manufacturer) \\
\hline $\mathrm{G}_{1}$ & Cyclin D1, D2, D3 + CDK4,6 & $\begin{array}{l}\text { Flavopiridol* (Sanofi-Aventis, Bridgewater, NJ) } \\
\text { PD-0332991* (Pfizer, New York, NY) } \\
\text { P276-00* (Piramal Life Sciences Limited, Mumbai, India) } \\
\text { PHA-848125* (Nerviano Medical Sciences, Nerviano, Italy) } \\
\text { LY2835219* (Eli Lilly, Indianapolis, IN) } \\
\text { LEE011* (Novartis, Basel, Switzerland) } \\
\text { Fascaplysin (Sigma-Aldrich, St. Louis, M0) } \\
\text { Cynnamaldehydes (Sigma-Aldrich) } \\
\text { AZD5438* (Astra Zeneca, London, England) } \\
\text { BAY 100394* (Bayer, Barmen, Germany) } \\
\text { P1446A-05* (Piramal Life Sciences Limited) } \\
\text { PD183812 (Pfizer) } \\
\text { Pyrrolo-carbazoles, indolocarbazoles, tryaminopyrimidine, dioxobenzothiazoles }\end{array}$ \\
\hline$S$ & $\begin{array}{l}\text { Cyclin } \mathrm{E}+\text { CDK2 } \\
\text { Cyclin A + CDK2 }\end{array}$ & $\begin{array}{l}\text { Flavopiridol* } \\
\text { SNS-032* (Sunesis Pharmaceuticals, South San Francisco, CA) } \\
\text { Bryostatin-1* (Tocris Bioscience, Ellisville, MO) } \\
\text { Roscovitin*(Cyclacel Pharmaceuticals, Short Hills, NJ) } \\
\text { Dinaciclib* (SCH727965) (Merck, Whitehouse Station, NJ) } \\
\text { P276-00* } \\
\text { PHA-848125* } \\
\text { UCN-01* (Sigma-Aldrich) } \\
\text { BAY 100394* } \\
\text { Olomucine (Sigma-Aldrich) } \\
\text { Purvalanol A (Tocris Bioscience) } \\
\text { Aloisines (Enzo Life Sciences, Farmingdale, NY) } \\
\text { Indirubins (Enzo Life Sciences) } \\
\text { Hymenialdisine (Enzo Life Sciences) } \\
\text { SU 9516 (Tocris Bioscience) } \\
\text { AZD5438* (Astra Zeneca), CVT-313 (Enzo Life Sciences), butyrolactone I (Sigma-Aldrich), } \\
\text { pyrazolo-pyridine (Sigma-Aldrich), pyrazolo-quinazolines (Astra Zeneca), indenopyrazoles } \\
\text { (Bristol-Myers Squibb, New York City, NY), nitroso-pyrimidines (Sigma-Aldrich) }\end{array}$ \\
\hline
\end{tabular}

*Compounds that have entered clinical development.

CDK, cyclin-dependent kinase.

Cdc6, ${ }^{11}$ and this complex phosphorylates $\mathrm{p} 27^{\mathrm{Kip} 1}$, further facilitating the entry of cells into $\mathrm{S}$ phase. ${ }^{9}$ It is thought that removal of $\mathrm{p} 27^{\mathrm{Kip}}$ from the cyclin E/CDK2 complex is essential for entry of cells into the $\mathrm{S}$ phase. ${ }^{7}$

CDK2 also forms a functional complex with cyclin A, a major E2F target gene. The cyclin A/CDK2 complex is necessary for proper DNA replication and synthesis in the $\mathrm{S}$ phase. ${ }^{12}$ In late $G_{2}$ and early $M$ phase, cyclin $A$ also associates with CDK1 to promote cell entry into the $\mathrm{M}$ phase. ${ }^{13}$ This occurs in part through the activity of CDK7 and cyclin $\mathrm{H}$ which form a regulatory complex referred to as the CDK-activating kinase. ${ }^{7}$ Finally, cell-cycle progression through $\mathrm{G}_{2}$ into the $\mathrm{M}$ phase is controlled by the cyclin $\mathrm{B} / \mathrm{CDK} 1$ complex, a tightly regulated and nonredundant cyclin/CDK complex that is required to promote the proper traversing of the cell into $\mathrm{M}$ phase. Ubiquitin-mediated 
Table 2 Cell-Cycle Abnormalities in Patients with Gastrointestinal Cancers

\begin{tabular}{|c|c|c|c|}
\hline Malignancy & Abnormality & Prevalence & Significance \\
\hline \multirow[t]{8}{*}{ Colon } & $\begin{array}{l}\text { CDK4/6 overexpression } \\
\text { Cyclin D2 }^{15} \\
\text { overexpression }\end{array}$ & & $\begin{array}{l}\text { Associated with APC loss and intestinal } \\
\text { proliferation }\end{array}$ \\
\hline & CDK4 overexpression $^{15}$ & $\begin{array}{l}\text { 74/74 specimens; } 33 / 74 \text { yielded } \\
\text { strong expression }\end{array}$ & $\begin{array}{l}\text { Strong expression-associated with } \\
\text { worse prognosis }\end{array}$ \\
\hline & CDK2 overexpression ${ }^{17}$ & $\begin{array}{l}86 \% \text { in carcinoma cells; } 28 \% \\
\text { in adenomas }\end{array}$ & \\
\hline & CDK1 overexpression $^{18}$ & & Higher risk of distant metastasis (HR, 6.2) \\
\hline & Cyclin D1 overexpression ${ }^{19,20}$ & $55 \%$ of tumors & Better overall mortality $(\mathrm{HR}, 0.74)$ \\
\hline & p16 overexpression ${ }^{15}$ & $73 / 74$ specimens & Better prognosis \\
\hline & Loss of $p 27^{21-23}$ & $10 \%$ tumors & Worse prognosis; risk ratio of death, 2.9 \\
\hline & p27 overexpression ${ }^{24}$ & $30 \%$ of tumors & \\
\hline \multirow[t]{6}{*}{ Esophagus } & $\begin{array}{l}\text { Chromosomal region for } \\
\text { CDK4 amplified } \\
25,26\end{array}$ & $10 \%$ & Worse overall survival \\
\hline & CDK4+6 amplification $^{25,26}$ & $4 / 116$ tumors & Poor survival \\
\hline & CDK1 overexpression $^{25,26}$ & $54 \%$ & Poor prognosis \\
\hline & CDK2 overexpression ${ }^{26}$ & $56 \%$ & \\
\hline & Cyclin D1 overexpression ${ }^{26}$ & $41 \%$ & Poor prognosis \\
\hline & p27 overexpression ${ }^{26}$ & & Poor survival; higher grade tumors \\
\hline \multirow[t]{6}{*}{ Stomach } & CDK4 overexpression $^{27}$ & $48 \%$ of 260 specimens & \\
\hline & Cyclin D1 overexpression ${ }^{27}$ & $34 \%$ of specimens & \\
\hline & Cyclin D2 overexpression ${ }^{27}$ & $30 \%$ of specimens & Disease progression \\
\hline & Cyclin E overexpression $^{27}$ & $44 \%$ of specimens & \\
\hline & Low p27 expression 27,28 & $62 \%$ & Poor survival (RR, 2.64) \\
\hline & Loss p $21^{29}$ & & Distant metastasis \\
\hline \multirow[t]{4}{*}{ Pancreas } & CDK4 overexpression ${ }^{19}$ & $50 \%-75 \%$ & \\
\hline & Cyclin D1 overexpression ${ }^{16}$ & $68 \%$ & Poor survival \\
\hline & p21 overexpression ${ }^{30,31}$ & $85 \%$ & \\
\hline & p16 Loss $^{19}$ & $83 \%$ & $\begin{array}{l}\text { Increased risk of early metastasis and } \\
\text { poor survival }\end{array}$ \\
\hline \multirow[t]{4}{*}{$\mathrm{HCC}$} & CDK4 overexpression ${ }^{24}$ & $73 \%$ & Poor survival \\
\hline & Cyclin D1 overexpression ${ }^{24}$ & $33 \%$ & Poor prognosis \\
\hline & Cyclin E overexpression ${ }^{24}$ & $36 \%$ & \\
\hline & p16 expression ${ }^{24}$ & $90 \%$ & \\
\hline \multirow[t]{2}{*}{ Biliary cancers } & Cyclin $\mathrm{D} 1^{22}$ & $62 \%$ & \\
\hline & p16 loss ${ }^{22}$ & $31 \%-40 \%$ & Poor prognosis \\
\hline
\end{tabular}

APC, adenomatous polyposis coli; CDK, cyclin-dependent kinase; HCC, hepatocellular carcinoma; HR, hazard ratio; RR, relative risk.

degradation of cyclin B1 is required for the cells to properly progress through mitosis. ${ }^{7}$

As mentioned earlier, the dysfunction of the cell cycle occurs in most human cancers as a result of aberrant cyclin and CDK function. ${ }^{14}$ Therefore, targeting CDK is a potentially effective strategy in developing cancer therapeutics (Table 1).

\section{Cell-Cycle Abnormalities in GI Tumors}

\section{Colon Cancer}

To get a better understanding of the mechanisms of tumorigenesis in GI cancers and to design better, moreeffective therapies, numerous studies have investigated the alterations in cell-cycle regulation that occur in GI tumors and the concomitant effects that these changes have on tumor aggressiveness, drug and radiation sensitivity, and overall patient outcome (Table 2). Perhaps, not surprisingly, the data underline the complexity of cell-cycle regulation and the importance of knowing which pathways are altered, on a patient-by-patient level, when designing therapeutic regimens. For example, Cole et $\mathrm{al}^{32}$ found that cyclin D2 and CDK4/6 are overexpressed after APC loss in the intestinal epithelium which suggests that deregulation of CDK4/6 is required for enterocyte proliferation and adenoma formation. In addition, Zhao et $\mathrm{al}^{33}$ evaluated paraffin sections of 74 cases of colorectal carcinoma and found stronger immunostaining of $\mathrm{p} 16^{\mathrm{INK} 4 \mathrm{a}}$ and CDK4 in the cytoplasm of carcinomas than in adenomas and adjacent normal tissue. Of the 74 specimens examined, 73 stained positive for $\mathrm{p} 16^{\mathrm{INK} 4 \mathrm{a}}$ of which 53 showed a strong expression pattern. Prognosis was substantially better for tumors with strong expression of $\mathrm{p} 16^{\mathrm{INK} 4 \mathrm{a}}$. The expression of $\mathrm{p} 16^{\mathrm{INK} 4 \mathrm{a}}$ and CDK4 was scored by multiplying the extent of positivity and its intensity and by grading it on a scale of 0 to 12 where strong staining was defined as a score of 9 to 12. All 74 specimens showed CDK4 expression, but only 33 
specimens showed strong expression. Stronger immunostaining for CDK4 was predictive of a worse prognosis $(P<0.001)$. Conversely, Ogino et $\mathrm{al}^{34}$ conducted an intriguing study to evaluate the prognostic relevance of cyclin D1, independent of other confounding variables such as p53, p21 ${ }^{\text {Cip1 }}$, p27 ${ }^{\mathrm{Kip} 1}, K R A S$ (alias Ki-ras), BRAF mutation, microsatellite instability, the $\mathrm{CpG}$ island methylator phenotype, and long-interspersed nuclear element-1 hypomethylation. Their cohort study of 602 patients with colon cancer found that cyclin D1 was overexpressed in 55\% of tumors. Surprisingly, cyclin D1 overexpression was associated with low cancer-specific mortality on multivariate regression analysis [hazard ratio (HR), 0.57; 95\% CI, $0.39-0.84 ; P=0.0048)$. A similar favorable trend was observed for overall mortality (HR, $0.74 ; 95 \% \mathrm{CI}$, $0.57-0.98 ; P=0.036$ ). These results indicate that cyclin D1 expression in colon cancer tumors may be associated with a favorable prognosis, a finding that was previously reported ${ }^{35}$ but contradicts the common belief about the poor prognosis of cyclin D1 and the observations by Zhao et $\mathrm{al}^{36}$ that reported the association of overexpression of the cyclin D1 heterodimeric partner CDK4 with worse prognosis.

Yamamoto et $\mathrm{al}^{12}$ found that CDK2 was overexpressed in a higher percentage of colon cancer tumor cells than of adenoma cells $\left(86 \%\right.$ versus $28 \%$ ), and Zeestraten et $\mathrm{al}^{37}$ found that elevated expression of CDK1 in tumor specimens from 254 patients with stage II colon cancer correlated with higher risk of distant metastasis (HR, 6.2; 95\% CI, 1.44-26.9; $P=0.012$ ). Moreover, CDK1 amounts were substantially elevated in microsatellite-stable tumors. This finding may be a result of the rigorous multivariate regression analysis conducted by the investigators or could be a statistical aberration. Loda et $\mathrm{al}^{38}$ examined a series of 149 primary human colorectal cancer (CRC) specimens and determined that absence of the CDKi p27 $7^{\text {Kip } 1}$ resulted in a risk ratio for death of $2.9(P=0.003)$. p $27^{\text {Kip } 1}$ expression was absent in $10 \%$ of tumors, low $(\leq 50 \%$ of cells staining positive) in $60 \%$ of tumors, and high ( $\geq 50 \%$ of cells staining positive) in $30 \%$ of specimens. Median survival was 69 months in tumors that lacked p2 $7^{\mathrm{Kip} 1}$ expression versus 151 months in $\mathrm{p} 27^{\mathrm{Kip} 1}$-positive tumors. These results indicated that the lack of $\mathrm{p} 27^{\mathrm{Kip} 1}$ expression conferred worse prognosis in patients with CRC. Subsequent studies found that loss of p27 ${ }^{\text {Kip } 1}$ expression (both nuclear and cytoplasmic) correlated with microsatellite instability in patients with $\mathrm{CRC},{ }^{17}$ highlighting an association between loss of CDKi and tumorigenesis. The same group also described a statistically significant association between cyclin D1 overexpression and microsatellite instability-high status $(P \leq 0.02) .{ }^{39}$ In addition, others have observed a positive association between $\mathrm{p} 21^{\mathrm{Cip} 1}$ overexpression and microsatellite instability-high status. ${ }^{40}$

\section{Gastroesophageal Cancer}

In esophageal cancer a study conducted by Ismail et $\mathrm{al}^{41}$ evaluated a cohort of 116 patients and found that the chromosomal region that contained CDK4 was amplified in
$10 \%$ of tumors and was associated with worse overall survival $(P=0.019)$. Only 4 of 116 tumors showed amplification of both CDK4 and CDK6, and this was associated with poor survival (HR, 2.1; $P=0.0008$ ). Similarly, loss of p2 $7^{\text {Kip1 }}$ expression correlated with higher grade $(P<0.001)$ and poor survival $(P=0.05) .{ }^{42}$ Takano et al, ${ }^{27}$ found that CDK4 overexpression was detected by immunohistochemistry (IHC) in $48 \%$ of 260 gastric cancer cases. Cyclin D1, $\mathrm{D} 2$, and $\mathrm{E}$ were overexpressed in $34 \%, 30 \%$, and $44 \%$ of cases, respectively. Overexpression of CDK4 and cyclin D2 and loss of p27 substantially correlated with tumor progression on univariate analysis. ${ }^{43}$ On multivariate analysis, only cyclin D2 and p27 $7^{\mathrm{Kip} 1}$ changes correlated with progression. In gastric cancer, Mori et $\mathrm{al}^{28}$ analyzed $\mathrm{p} 27^{\mathrm{Kip} 1}$ expression in 138 patients. Low $227^{\text {Kip } 1}$ expression was present in $62 \%$ of tumors and correlated significantly with increased tumor size, invasion outside the gastric wall, the presence of lymph node metastasis, and higher stage. Loss of $\mathrm{p} 27^{\mathrm{Kip} 1}$ staining was independent of prognostic markers for survival on multivariate analysis (relative risk, 2.64; $P<0.01$ ). Similar results were observed with $\mathrm{p} 21^{\mathrm{Cip} 1}$. The loss of $\mathrm{p} 21^{\mathrm{Cip} 1}$ predicted increasing histologic grade, depth of invasion, and distant metastasis in patients with gastric cancer. $^{29}$

\section{Pancreatic Cancer}

Cell-cycle abnormalities are frequently observed in pancreatic cancer. Cyclin D1 overexpression was found in $68 \%$ of pancreatic cancer specimens with the use of IHC, ${ }^{28}$ consistent with the known induction of cyclin D1 by oncogenic ras, ${ }^{15}$ a driver oncogene in pancreatic cancer. In addition, Southern blot analyses revealed amplification of the cyclin D1 coding region in $25 \%$ of the pancreatic cancer specimens, and mRNA was overexpressed with RT-PCR in $82 \%$ of the examined tissue. ${ }^{16}$ Investigators have also reported that cyclin D1 overexpression correlated with poor survival (median survival, 18.1 months versus 10.5 months for normal expression versus cycling D1 overexpression; $P<0.01)$. Overexpression of CDK4 and CDK2 was noted in approximately $10 \%$ of pancreatic intraepethelial neoplasia (PanIN) 1B lesions. Although there was a progressive increase in higher grades of PanIN and invasive cancer, the trend was not statistically significant. The median percentage of expression was $60 \%$ to $75 \%$ in carcinoma cells. ${ }^{19}$ In pancreatic cancer, $\mathrm{p} 21^{\text {Cip } 1}$ overexpression is also common and appears to be an early event in pancreatic neoplasia. An analysis by Biankin et $\mathrm{a}^{44}$ found that $\mathrm{p} 21^{\mathrm{Cip} 1}$ overexpression was present in $9 \%$ of normal pancreatic ducts, $16 \%$ of PanIN1A lesions, 32\% of PanIN1B lesions, $56 \%$ of PanIN2 lesions, and $85 \%$ of patients with pancreatic adenocarcinoma $(P<0.01)$. Similarly, p16 ${ }^{\mathrm{INK} 4 \mathrm{a}}$ inactivation was observed in the majority $(83 \%)$ of pancreatic cancer tumors in a study conducted by Rozenblum et al. ${ }^{20}$ It was also thought to be an early event in pancreatic tumorigenesis. ${ }^{18}$ Sasaki et $\mathrm{al}^{18}$ observed that partial loss of 
p16 ${ }^{\mathrm{INK} 4 \mathrm{a}}$ expression was observed in 9 of 16 and 12 of 13 pancreatic adenoma and carcinoma samples, respectively. In addition, low amounts of $\mathrm{p} 16^{\mathrm{INK} 4 \mathrm{a}}$ expression were associated with larger tumors, risk of early metastasis, and poor survival. ${ }^{18}$

\section{Hepatocellular Carcinoma}

Several studies have evaluated the expression of cell-cycle proteins in hepatocellular carcinoma (HCC) cells. A study by Ito et $\mathrm{al}^{24}$ found that $\mathrm{p} 21^{\mathrm{Kip} 1}$ was expressed when evaluated by IHC in 54 of 104 specimens. p21 ${ }^{\text {Kip } 1}$ expression was substantially higher in cases of intrahepatic metastasis, but no other correlation could be established between p $21^{\text {Kip } 1}$ and the tumors' clinicopathologic features. $16^{\mathrm{INK} 4 \mathrm{a}}$, however, was expressed in 94 of 104 cases. The labeling index of $16^{\mathrm{INK} 4 \mathrm{a}}$ in HCC cells was lower in stages III or IV than in stages I and II $(36.5 \pm 26.8$ versus $51.0 \pm 28.2$; $P=0.121)$. The labeling index of $\mathrm{p} 27^{\mathrm{Kip} 1}$ was overexpressed in HCC cells and was substantially decreased in cases with portal invasion, poor differentiation, and larger tumor size. Cyclin D1 was overexpressed in 34 of 104 HCC specimens. Overexpression of cyclin D1 was associated with higher Ki-67 and poor differentiation. Similarly, cyclin E was overexpressed in 37 of 104 specimens, and its overexpression was associated with higher $\mathrm{Ki}-67$ and higher stage. ${ }^{24}$ A study by Lu et al ${ }^{21}$ found that CDK4 was overexpressed by IHC in $73 \%$ of 59 specimens. Overexpression of CDK4 was an independent prognostic factor for poor survival.

\section{Biliary Cancers}

Cell-cycle abnormalities are also common in biliary neoplasm. Cyclin D1 overexpression was observed in $62 \%$ of patients with intrahepatic cholangiocarcinoma. In addition, loss of $\mathrm{p} 16^{\mathrm{INK} 4 \mathrm{a}}$ and $\mathrm{p} 27^{\mathrm{Kip} 1}$ was detected in $31 \%$ and $12 \%$ of tumors, respectively. ${ }^{22}$ Similarly, another study found that $\mathrm{p} 16^{\mathrm{INK} 4 \mathrm{a}}$ expression was lost in $40 \%$ of extrahepatic biliary neoplasms and was associated with poor prognosis. ${ }^{45}$ In gallbladder cancer, cyclin D1 overexpression was detected in $41 \%$ of the examined specimens. Cyclin D1 overexpression was significantly associated with decreased overall survival $(P<0.05)$ in those patients. ${ }^{23}$

\section{Genetic Alternations Affecting the Cell-Cycle Components in GI Tumors}

The association between genetic mutations and CDK overexpression has been the focus of several studies. Grady et $\mathrm{al}^{46}$ found that CDK4 overexpression was found in colorectal tumors that carry type II transforming growth factor- $\beta$ receptor mutations, a mutation that results in tumor microsatellite instability. These results are important because approximately $15 \%$ of human colon cancers have microsatellite instability caused by this mutation ${ }^{46}$ and provided evidence that deregulation of CDK 4 can be a consequence of transforming growth factor- $\beta$ receptor mutations. Similarly, inherited mutation of $C D K N 2 A$ (the gene that encodes $\left.\mathrm{p} 16^{\mathrm{INK} 4 \mathrm{a}}\right)^{25}$ is responsible for familial cutanenous melanoma and was associated with an increased risk of pancreatic cancer in families that harbor the mutation. The CDKN2A gene is located on chromosome 9p, the most frequently inactivated gene in pancreatic cancer. ${ }^{47}$ Loss of $\mathrm{p} 16^{\mathrm{INK} 4 \mathrm{a}}$ in pancreatic cancer can also occur through homozygous deletion (40\%), single allelic loss associated with a mutation in the second allele (40\%), and promoter hypermethylation (15\%). ${ }^{47}$ The $C D K N 2 A$ gene was also found to be inactivated in $40 \%$ of colon cancers. ${ }^{48}$ The inactivation of $C D K N 2 A$ was thought to be secondary to de novo methylation of $5^{\prime} \mathrm{CpG}$ island of the gene. ${ }^{30}$ Cyclin D1 protein overexpression is rather common in CRC. ${ }^{49}$ The mechanism of cyclin D1 overexpression is thought to be secondary to transcription activation of the CCND1, the gene coding for cyclin D1. A study by Bondi et al, ${ }^{31}$ however, found that extra gene copies of cyclin D1 were seen in 50\% of 219 colon adenocarcinoma tumors. Another study suggested copy number changes, predominately gains (7.6\%) and rarely amplifications $(2.5 \%)$, may be associated with the increase in the cyclin D1 expression. ${ }^{31}$ These results suggest that several mechanisms may contribute to the overexpression of cyclin D1 in patients with CRC. Taken together, these studies suggest cell-cycle abnormalities occur frequently in GI tumors. It appears that overexpression of CDK and cyclins and by contrast loss of CDKis such as $\mathrm{p} 21^{\mathrm{Cip} 1}$ and $\mathrm{p} 27^{\mathrm{Kip} 1}$ are associated with less favorable tumor phenotypes and poor prognosis. Therefore, targeting the cell cycle represents a promising treatment modality and perhaps identifying patients who have abnormalities in the cell-cycle machinery, either through IHC or genetic sequencing, may enrich the population of patients most likely to respond to treatment with agents that target the cell-cycle abnormalities. Currently, many cell-cycle-targeting agents are in various stages of clinical development (Table 1).

\section{Preclinical Data for Cell-Cycle Inhibitors in GI Tumors}

\section{Colon Cancer}

Preclinical models have evaluated the use of pharmacologic CKDis in solid tumors and GI malignancies. ${ }^{50,51}$ PD-0332991 (palbociclib; Pfizer, New York, NY) is an orally administered, highly specific inhibitor of CDK4 and CDK6. In mice bearing Colo-205 human colon carcinoma, PD-0332991 produced marked tumor regression. ${ }^{50}$ With 14 days of therapy at a dose of $150 \mathrm{mg} / \mathrm{kg}$, there was a tumor growth delay of 50 days and greater than on log of tumor-cell kill. Retreatment of the tumors with PD-0332991 was not associated with development of resistance. As expected from a CDK4/6 inhibitor, PD-0332991 administration eliminated phosphorylated $\mathrm{Rb}$, down-regulated genes 
regulated by $\mathrm{E} 2 \mathrm{~F}$, and caused a $\mathrm{G}_{1}$ cell-cycle arrest. Conversely, PD-0332991 was not active against Rbnegative tumors. Similarly, Yamamoto et $\mathrm{al}^{12}$ evaluated the use of butyrolactone I, a specific CDK2 inhibitor, in four colon cancer cells lines (HCT116, LoVo, HT29, Colo 320DM). Butyrolactone I inhibited proliferation of the four colon cancer cell lines and induced apoptosis in the LoVo cell line with induction of p53. Another CDK2 inhibitor, SU 9516 (Tocris Bioscience, Ellisville, MO), was investigated by Lane et $\mathrm{al}^{52}$ in human colon cancer cell lines (RKO, SW480, and Colo250). Administration of SU 9516 resulted in selective inhibition of CDK2 and either $\mathrm{G}_{0}$ to $\mathrm{G}_{1}$ or a $\mathrm{G}_{2}$ to $\mathrm{M}$ arrest. A novel pan-CDK inhibitor RGB 286199 was also investigated in human colon carcinoma cell line HCT-116. ${ }^{53}$ Cell lines treated with RGB 286199 showed loss of Rb phosphorylation, accompanied by loss of cyclin A protein. In vivo, RGB 286199 results in cell-cycle arrest and loss of viability. CDKi combination with DNA-damaging agents was also investigated in preclinical models. Takagi et $\mathrm{al}^{54}$ found that the CDKi SU 9516 reduced the expression of thymidylate synthase in human CRC DLD-1 cells. This effect enhanced the sensitivity of colon cancer cells to 5-fluorouracil (5-FU) and suggested that a CDKi/5-FU combination may be a promising future treatment option. Correspondingly, Pishvaian et $\mathrm{al}^{42}$ found that the combination of PD-0332991 and oral 5-FU (capecitabine) resulted in synergistic anticancer activity in mice bearing HCT-116 colon cancer xenografts. Similarly Ziemke et $\mathrm{al}^{55}$ found that the combination of PD-0332991 and multiple mitogen-activated protein extracellular signal-related kinase inhibitors was associated with higher frequency of regression of colon cancer cell lines compared with either agent alone. These data suggest that combination therapy, including cell-cycle inhibitors, may be a promising strategy in treating patients with CRCs.

\section{Hepatocellular Carcinoma}

PD-0332991 was also evaluated in human hepatocellular carcinoma cells Huh7, HepG2, and Hep3B and xenograft models that harbor $\mathrm{Rb}$ knockdown and mice with liver-specific $\mathrm{Rb}$ deletion. ${ }^{51}$ PD-0332991 resulted in arrest of cell-cycle progression in hepatoma cells, irrespective of $\mathrm{Rb}$ status. The model suggested that cell-cycle arrest can be achieved in Rb-deficient tumors exposed to CDK4/6 inhibitors. Pishvaian et al ${ }^{56}$ found that most hepatoma cell mouse models exhibit increased expression of cyclin D1 and CDK4. Moreover, in human HCC cell lines, PD-0332991 inhibited cell growth by 30\%. This was associated with a decrease in cyclin E expression. Finally, PD-0332991 antitumor effects were additive to doxorubicin in HepG2 xenografts. These results suggest that CDK4/6 inhibition may be a feasible treatment for HCC.

\section{Gastroesophageal Carcinoma}

Investigators have combined flavopiridol (Sanofi-Aventis, Bridgewater, NJ) with radiation therapy in a human esophageal adenocarcinoma (SEG-1) cell model. ${ }^{57}$ This model showed that flavopiridol given before or after radiation therapy exhibits a radiosensitizing effect. The cells were arrested at the $G_{1}$ phase of the cell cycle. Moreover, flavopiridol enhanced radiation-induced apoptosis and inhibited transcription activity as evidence by reduction in RNA polymerase II. These results suggested that CDKis can potentially be combined with radiation therapy as radiosensitizers. Moreover, PD-0332991 was shown to have potent antiproliferative activity at low nanomolar range in multiple gastric cancer cell lines. Of note, cyclin D1- and HER2amplified cells exhibited greater sensitivity to this agent. In addition, combination therapy of trastuzumab and PD03329991 indicated substantial synergy in HER2-amplified gastric cancer models. ${ }^{58}$

\section{Pancreatic Cancer}

Studies in pancreatic cancer cell lines suggested that the CDKi flavopiridol (alvocidib) has synergistic activity when combined with gemcitabine, a commonly used chemotherapeutic agent in pancreatic cancer. ${ }^{59}$ The observed synergy is mediated through up-regulation of RR-M2, a DNA enzyme involved in DNA synthesis and gemcitabine resistance that is regulated by E2F. Similarly, another study found that treatment of pancreatic cancer cell lines with E2F-1 virus and roscovitine (Seliciclib; CYC202; Cyclacel Pharmaceuticals, Short Hills, NJ), a CDK2, CDK7, and CDK9 inhibitor, results in an additive effect on cell growth inhibition and induction of apoptosis. ${ }^{60}$ In addition, investigators have reported that roscovitine can effectively block the proliferation of human pancreatic cancer cells, regardless of their mutational status of KRAS, $p 53$, or $p 16$ genes. ${ }^{61}$

\section{Clinical Data for Cell-Cycle Inhibitors in GI Tumors}

Flavopiridol remains the most extensively studied CDKi in solid tumors and specifically in GI cancers. Flavopiridol inhibits CDK1, CDK2, CDK4, CDK7, and CDK9 by their respective ATP-binding sites. ${ }^{62}$ Flavopiridol also has the ability to enhance apoptosis induced by chemotherapy. ${ }^{62}$ It is thought that the proapoptotic effect of flavopiridol is mediated through the inhibition of antiapoptotic genes at the transcription level. ${ }^{63}$ This effect is often sequence dependent. As an example, tumor cell killing is enhanced when flavopiridol is administered after exposure to taxanes. ${ }^{64}$ Flavopiridol was therefore investigated in combination with chemotherapy agents. For example, flavopiridol was tested in combination with irinotecan by Shah et $\mathrm{al}^{65}$ in a phase 1 trial that involved 45 patients with advanced malignancies. Irinotecan was administered first, followed 7 hours later by escalating doses of flavopiridol administered over 1 hour weekly 4 weeks on/2 weeks off. The recommended phase 2 dose was irinotecan $100 \mathrm{mg} / \mathrm{m}^{2} /$ flavopiridol $60 \mathrm{mg} / \mathrm{m}^{2}$ or irinotecan $125 \mathrm{mg} / \mathrm{m}^{2} /$ flavopiridol $50 \mathrm{~m} / \mathrm{m}^{2}$. At 
irinotecan dose of $125 \mathrm{mg} / \mathrm{m}^{2} /$ flavopiridol $60 \mathrm{mg} / \mathrm{m}^{2}$, doselimiting hyperbilirubinemia, fatigue, and myelosuppression were observed. Three patients had a partial response (PR), and $36 \%$ of patients had prolonged stable disease (SD) $(>6$ months). Of the 27 patients with CRC, 14 (52\%) had SD, 1 had PR, and 12 patients (44\%) had progressive disease. The median duration of disease control (PR $+\mathrm{SD}$ ) was 6.8 months. Flavopiridol was also evaluated in a phase 1 trial of 48 patients with advanced solid tumors in combination with FOLFOX (5-FU, leucovorin, and oxaliplatin). ${ }^{66}$ Patients were treated with a biweekly sequential regimen of flavopiridol at a starting dose of $40 \mathrm{mg} / \mathrm{m}^{2}$ over 1 hour, concomitant oxaliplatin at a starting dose of $60 \mathrm{mg} / \mathrm{m}^{2}$ and leucovorin, followed by a bolus of 5-FU at a fixed dose of $400 \mathrm{mg} / \mathrm{m}^{2}$ and continuous 5-FU at a starting dose of 1800 $\mathrm{m} / \mathrm{m}^{2}$. The maximum tolerable doses (MTDs) were flavopiridol $70 \mathrm{mg} / \mathrm{m}^{2}$, oxaliplatin $85 \mathrm{mg} / \mathrm{m}^{2}$, and 5-FU 1800 $\mathrm{mg} / \mathrm{m}^{2}$ continuous infusion. Encouraging clinical activity was noted in platinum-resistant germ cell tumors. Responses were also observed in pancreatic and gastric cancers. A similar regimen was evaluated by Meng et $\mathrm{al}^{67}$ in a phase 1 trial that involved 19 patients with advanced solid tumors. The regimen included a fixed $40-\mathrm{mg} / \mathrm{m}^{2}$ dose of flavopiridol administered over 1 hour concurrently with escalating doses of oxaliplatin given as part of a modified FOLFOX6 regimen given at standard doses every 2 weeks. Grade 3 hyponatremia and syncope were encountered at an oxaliplatin dose of $85 \mathrm{mg} / \mathrm{m}^{2}$ and $5-\mathrm{FU}$ dose of $1200 \mathrm{mg} / \mathrm{m}^{2}$ per day. This regimen was clinically active with one PR in a patient with pancreatic cancer and SD in gastric cancer, anal cancer, and CRC. Flavopiridol was also evaluated in a phase 1 trial in combination with standard dose of 5-FU and irinotecan (FOLFIRI) every 2 weeks. ${ }^{68}$ Two assessments of the MTD were planned. $\mathrm{MTD}_{1}$ was evaluated with flavopiridol administered over 1 hour, and $\mathrm{MTD}_{2}$ was evaluated with flavopiridol as a 30-minute bolus followed by a 4-hour infusion. Seventy-four patients were treated, 63 were evaluable for toxicity and 56 for response. $\mathrm{MTD}_{1}$ of flavopiridol was $80 \mathrm{mg} / \mathrm{m}^{2}$ and the dose-limiting toxicities (DLTs) were diarrhea, fatigue, neutropenia, and neuropathy. $\mathrm{MTD}_{2}$ was a bolus of $35 \mathrm{mg} / \mathrm{m}^{2}$ and $35 \mathrm{mg} / \mathrm{m}^{2}$ over 4 hours. DLTs were diarrhea, neutropenia, and fatigue. Of 25 patients with CRC, 11 had SD lasting $>3$ months (median, 6 months; range, 4.2 to 15.4 months), despite prior progression on $\geq 1$ irinotecan-containing regimen. Six of those patients had significant reduction (36\% to $78 \%$ ) in their carcinoembryonic antigen amounts. One patient with small bowel cancer had a PR that lasted 10.3 months.

Phase 2 trials of flavopiridol include a single-agent study with flavopiridol in patients with previously untreated advanced CRC. ${ }^{69}$ Twenty patients were treated with flavopiridol at a dose of $50 \mathrm{mg} / \mathrm{m}^{2}$ per day as a 72-hour continuous infusion every 2 weeks. No objective responses were observed, and five patients had SD that lasted a median of 7 weeks, the median survival was 65 weeks, and the median time to progression was 8 weeks. The most commonly occurring toxicities were diarrhea (21\%), fatigue $(11 \%)$, and hyperglycemia $(11 \%)$. A similar regimen of flavopiridol was investigated in 16 patients with advanced gastric cancer. There were no objective responses. Grade 3 or 4 fatigue and diarrhea occurred in $27 \%$ and $20 \%$ of patients, respectively. An unexpectedly high number of patients (5 of 14 evaluable patients) developed central lineassociated venous thrombosis. This study added more evidence that flavopiridol has minimal activity as a single agent. Attention was therefore shifted to the role of flavopiridol in combination with other chemotherapeutic agents. Flavopiridol was evaluated in phase 2 trials in combination with docetaxel in 10 patients with refractory metastatic pancreatic cancer. $^{70}$ The regimen included docetaxel $35 \mathrm{mg} / \mathrm{m}^{2}$ followed by flavopiridol $80 \mathrm{mg} / \mathrm{m}^{2}$ on days 1,8 , and 15 of a 28 day cycle. Three patients had SD, and median survival was 4.2 months. Adverse events (AEs) included transaminitis $(11 \%)$, grade 4 neutropenia, grade 3 fatigue, and grade 3 diarrhea. This regimen was thought to have minimal activity in patients with pancreatic cancer. Although preclinical studies of flavopiridol sparked optimism about the role of flavopiridol as a new option for cancer treatment, clinical studies to date have not found that it possesses any meaningful activity as single agent or combination in GI tumors, likely because of the substantial toxicity that may be a result of pan-CDK inhibition and off-target effects.

PD-0332991 has gained interest because it is a selective CDK4/6 inhibitor. It was investigated in two phase 1 clinical trials. PD-0332991 was administered for 14 days, followed by 7 days off treatment to 33 patients with Rb-positive advanced solid cancers. ${ }^{71,72}$ Six patients had colon cancer. The MTD was $200 \mathrm{mg}$ daily. Six patients (18\%) had DLTs. Treatment-related AEs were encountered in 29 patients $(88 \%)$. These AEs were generally mild to moderate. The most common nonhematologic AEs were fatigue, nausea, diarrhea, constipation, epistaxis, and rash. Grade 3 and 4 hematologic toxicity included neutropenia (24\%), leukopenia (21\%), thrombocytopenia (9\%), and anemia (3\%). No responses were reported in patients with GI malignancies. A second phase 1 dose escalation trial was conducted with the use of a 21 days on, 7 days off schedule. Forty-one patients were enrolled, including three with CRC, in six-dose escalation cohorts in a standard $3+3$ fashion. The MTD was $125 \mathrm{mg}$. Five patients (12\%) experienced DLTs. Neutropenia was the only DLT. After cycle 1, neutropenia, leukopenia, and anemia occurred in five patients $(12 \%)$, one patient $(2 \%)$, and three patients $(7 \%)$, respectively. The most common nonhematologic AEs were fatigue, nausea, and diarrhea. Of the patients with GI cancers, SD was observed in one patient with appendiceal carcinoma treated at the 100-mg dose until the time of data cutoff (39 cycles).

PD-0332991 was investigated in a phase 2 trial in patients with HCC. Patients with refractory HCC received PD0332991 at a dose of $125 \mathrm{mg}$ daily for 3 weeks with a 1-week break. Preliminary results from 10 patients indicated 
Table 3 Predictive Biomarkers for CDK4/6 Inhibitors

\begin{tabular}{|c|c|c|c|c|}
\hline Author & Agent & Setting $(n)$ & Biomarker & Outcome \\
\hline Wainberg $^{58}$ & PD-0332991 & $\begin{array}{l}\text { Gastric cancer cell lines (17) } \\
\text { Colon cancer cell lines (27) }\end{array}$ & $\begin{array}{l}\text { Cyclin D1 amplification } \\
\text { Cyclin E } \\
\text { p16 loss } \\
\text { p21 gain }\end{array}$ & $\begin{array}{l}\uparrow \text { Sensitivity } \\
\uparrow \text { Resistance } \\
\uparrow \text { Resistance } \\
\uparrow \text { Resistance }\end{array}$ \\
\hline Konecny $^{78}$ & PD-0332991 & Ovarian cancer cell lines (40) & p16 low expression & $\uparrow$ Sensitivity \\
\hline Finn $^{79}$ & PD-0332991 & Breast cancer cell line (47) & $\begin{array}{l}\text { p16 decrease } \\
\text { Cyclin D1 increase } \\
\text { pRb }\end{array}$ & $\begin{array}{l}\uparrow \text { Sensitivity } \\
\uparrow \text { Sensitivity } \\
\uparrow \text { Sensitivity }\end{array}$ \\
\hline von Euw $^{77}$ & PD-0332991 & Melanoma cell lines & Hedgehog pathway activation & $\uparrow$ Resistance \\
\hline
\end{tabular}

CDK, cyclin-dependent kinase; pRb, phosphorylated retinoblastoma.

that the most common toxicities were neutropenia and thrombocytopenia. Three patients developed grade 3 neutropenia that required treatment delay. Preliminary efficacy results were encouraging with four patients remaining on the trial with the best progression-free survival being 8 months. $^{73}$ Of note, other CDK4/6 inhibitors, LY2835219 (Eli Lilly, Indianapolis, IN) and LEE011 (Novartis, Basel, Switzerland), ${ }^{74-76}$ have also entered clinical development and have shown promising activity in breast cancer, lung cancer, and other solid tumors. In a preliminary report, LEE01 has demonstrated encouraging activity and safety profiles in a phase 1 study in patients with advanced solid tumors. ${ }^{75}$ Furthermore, a preliminary report of LY2835219 suggested that it had a favorable safety profile as monotherapy in metastatic breast cancer and in combination with fulvestrant in hormone-receptor-positive breast cancer. ${ }^{76}$ As monotherapy, LY2835219 had promising clinical activity [eight confirmed and three unconfirmed PR $(n=47)]$. Clinical activity of the combination was not reported, however, because of the preliminary nature of the report. Similarly, a phase 1 study of LY2835219 in 49 patients with advanced non-small cell lung cancer indicated an encouraging safety profile. Disease control rate was $51 \%$ with one confirmed PR. ${ }^{74}$ To date, this is the most encouraging data to indicate that cell-cycle inhibitors may have promising antitumor activity and an acceptable safety profile.

Emerging evidence suggests that certain aberrations in cell-cycle proteins could predict clinical outcome of patients treated with CDK4/6 inhibitors ${ }^{58,77-79}$ (Table 3). These data, although preliminary, may allow for selection of subgroups of patients that may preferentially benefit from treatment with CDKis.

BAY 1000394 (Bayer, Barmen, Germany) is also a panCDKi that targets CDK1, CDK2, CDK4, CDK7, and CDK9 but is available in tablet form and as an oral solution. A recent report of a phase 1 trial of BAY 1000394 as an oral solution suggested limited tolerability with a regimen of 28 days on/14 days off. The main DLTs were hyponatremia and hypokalemia. Four of 10 patients, however, had SD, including a patient with esophageal cancer who had SD for 2.5 to 3 months. ${ }^{80}$ Interestingly, when the same agent was administered in tablet form with the regimen of 3 days on/4 days off, it showed acceptable tolerability. ${ }^{81}$ Main grade 3 AEs were asthenia, nausea, and vomiting. SD was observed in 9 of 34 patients, including 1 patient with cholangiocarcinoma who had SD that lasted for 5 months.

UCN-01 (Sigma-Aldrich, St. Louis, MO) is another cellcycle inhibitor that has gained interest recently. ${ }^{82}$ p53deficient cells depend on activation of Chk1 pathway for $\mathrm{G}_{2}$ cell-cycle arrest and DNA repair after DNA damage. ${ }^{83}$ This pathway represents a survival pathway for tumor cells. UCN-01 inhibits Chk1 and Chk2 kinases, thereby leading cells to exit the $G_{2}$ phase before DNA repair can be completed. $^{82}$ This mechanism forces cells to undergo apoptosis. The clinical utility of UCN-01 was complicated by the development of UCN-01-related hyperglycemia. ${ }^{84}$ This complication was reported in patients with and without diabetes mellitus. Grade 3 and 4 hyperglycemia, occasionally requiring hospitalization, was reported in patients who received UCN-01. The cause of hyperglycemia remains unclear. There is evolving evidence, however, that inhibition of the phosphatidylinositol-3 kinase signaling protein AKT and downstream targets of the insulin receptor are responsible for the UCN-01-induced hyperglycemia. ${ }^{85}$ Other Chk1 inhibitors, such as CHIR124 and 17-AAG, are currently in clinical development. ${ }^{86,87}$ They differ structurally from UCN-01 and have shown encouraging preclinical data.

Bryostatin (Tocris Bioscience) is a cell-cycle inhibitor that induces $\mathrm{p} 21^{\mathrm{Kip} 1}$, resulting in inactivation of CDK2 and inhibition of tumor cell growth. ${ }^{87,88}$ Phase 1 studies of bryostatin found that myalgia is the DLT. ${ }^{88,89}$ Phase 2 studies of bryostatin in GI cancers were conducted. ${ }^{90,91}$ The combination of bryostatin with paclitaxel was explored in pancreatic cancer and proved to be ineffective. The paclitaxel/bryostatin combination was also explored in esophageal cancer. This regimen was, however, found to be associated with grade $3 / 4$ myalgia in $50 \%$ of patients. In another phase 2 clinical trial, bryostatin did not find any substantial single-agent clinical activity in colon cancer.

$R$-roscovitine (Seliciclib; CYC202; Cyclacel Pharmaceuticals) is also an inhibitor of CDK2, CDK7, and CDK9. One phase 1 trial was completed and found that nausea, vomiting, asthenia, and hypokalemia were DLTs. ${ }^{92}$ One patient with HCC experienced a PR. 
Other CDK2 inhibitors include SNS-032 (Sunesis Pharmaceuticals, South San Francisco, CA) ${ }^{93}$ (formerly BMS387032) and imidazopyridines ${ }^{94}$ that are undergoing early phases of development. Several other new cell-cycle inhibitors are currently in various stages of development (Table 1).

\section{Conclusion and Future Directions}

It is well documented that abnormal cell division is the hallmark of the initiation and progression of cancers. The role of cell-cycle inhibition as an effective and durable cancer treatment modality remains yet to be fully elucidated, in part because of the complexity of the cell cycle and the known compensatory function of some of the cyclins and CDKs. ${ }^{88}$ Although cell-cycle abnormalities are commonly observed in GI tumors, to date, efficacy of CDKis was at best modest in these tumors. Flavopiridol has been the most extensively studied CDKi and has shown disappointing results both alone and in combination therapy. Nevertheless, other cell-cycle inhibitors may prove to be clinically useful as monotherapy or in various combinations. PD-0332991 has shown encouraging activity as monotherapy in liposarcoma and non-small cell lung cancer and in combination with letrozole in breast cancer. ${ }^{95-97}$ Further research is also needed to explore the use of cell-cycle inhibitorcontaining combinations in GI tumors, to identify the patients most likely to benefit, and to determine the mechanisms of resistance to this novel class of drugs. Finally, one of the most important obstacles to the effective application of personalized medicine has been the inability to perform meaningful testing for drug sensitivity on the patient's own tumor cells. This unmet need was recently addressed by a powerful new epithelial cell culture technique developed at Georgetown University and the National Institutes of Health. Termed conditionally reprogrammed cells, this approach allows for the rapid and prolonged culturing of primary epithelial cells and is now applied to a wide variety of both normal epithelium and epithelial cancers. ${ }^{98-100}$ In fact, we have recently applied the conditionally reprogrammed cell approach to successfully diagnose and treat a patient who was succumbing to a rare, malignant form of recurrent respiratory papillomatosis. ${ }^{101}$ The patient had endured 350 operations to clear his respiratory track of cancerous obstructions and had failed numerous other attempts at therapeutic intervention. Within 14 days of initial culturing of the patient's normal and malignant cells, the causative underpinning of the disease was defined, and, importantly, a drug approved by the US Food and Drug Administration was identified (vorinostat) which selectively killed the tumor cells and not the normal epithelium at therapeutic doses. The patient responded extremely well to vorinostat treatment and remains alive to date, a major advancement because the window for surgical intervention was closing as a result of the scarring associated with the previous operations. Obviously, much emphasis is being placed on validating the possibility of a broad application of this approach to many tumor types, including GI cancers, and we have recently reported on the use of prostate-derived conditionally reprogrammed cells for the testing of novel therapeutic compounds. ${ }^{100,102}$ Should the conditionally reprogrammed cell approach continue to prove to be a robust method for drug sensitivity testing, the possibility exists that patient outcomes, similar to those described for the papillomatosis patient above, may become a reality for rapidly testing a GI patient's tumor cells against a battery of CDKis and other therapeutic compounds.

\section{References}

1. Dickson MA: Molecular pathways: CDK4 inhibitors for cancer therapy. Clin Cancer Res 2014, 20:3379-3383

2. Takayama T, Ohi M, Hayashi T, Miyanishi K, Nobuoka A, Nakajima T, Satoh T, Takimoto R, Kato J, Sakamaki S, Niitsu Y: Analysis of K-ras, APC, and beta-catenin in aberrant crypt foci in sporadic adenoma, cancer, and familial adenomatous polyposis. Gastroenterology 2001, 121:599-611

3. Irrazabal T, Belcheva A, Girardin SE, Martin A, Philpott DJ: The multifaceted role of the intestinal microbiota in colon cancer. Mol Cell 2014, 54:309-320

4. Sherr CJ: Cancer cell cycles. Science 1996, 274:1672-1677

5. Norbury C, Nurse P: Animal cell cycles and their control. Annu Rev Biochem 1992, 61:441-470

6. Meyerson M, Enders GH, Wu CL, Su LK, Gorka C, Nelson C, Harlow E, Tsai LH: A family of human cdc2-related protein kinases. EMBO J 1992, 11:2909-2917

7. Pestell RG, Albanese C, Reutens AT, Segall JE, Lee RJ, Arnold A: The cyclins and cyclin-dependent kinase inhibitors in hormonal regulation of proliferation and differentiation. Endocr Rev 1999, 20 $501-534$

8. Sherr CJ, Roberts JM: CDK inhibitors: positive and negative regulators of G1-phase progression. Genes Dev 1999, 13:1501-1512

9. Sherr CJ: G1 phase progression: cycling on cue. Cell 1994, 79: $551-555$

10. Bracken AP, Ciro M, Cocito A, Helin K: E2F target genes: unraveling the biology. Trends Biochem Sci 2004, 29:409-417

11. Khleif SN, DeGregori J, Yee CL, Otterson GA, Kaye FJ, Nevins JR, Howley PM: Inhibition of cyclin D-CDK4/CDK6 activity is associated with an E2F-mediated induction of cyclin kinase inhibitor activity. Proc Natl Acad Sci U S A 1996, 93:4350-4354

12. Yamamoto H, Monden T, Miyoshi H, Izawa H, Ikeda K, Tsujie M, Ohnishi T, Sekimoto M, Tomita N, Monden M: Cdk2/cdc2 expression in colon carcinogenesis and effects of $\mathrm{cdk} 2 / \mathrm{cdc} 2$ inhibitor in colon cancer cells. Int J Oncol 1998, 13:233-239

13. Murray AW: Recycling the cell cycle: cyclins revisited. Cell 2004 $116: 221-234$

14. Senderowicz AM: Small-molecule cyclin-dependent kinase modulators. Oncogene 2003, 22:6609-6620

15. Albanese C, Johnson J, Watanabe G, Eklund N, Vu D, Arnold A, Pestell RG: Transforming p21ras mutants and c-Ets-2 activate the cyclin D1 promoter through distinguishable regions. J Biol Chem 1995, 270:23589-23597

16. Gansauge S, Gansauge F, Ramadani M, Stobbe H, Rau B, Harada N, Beger HG: Overexpression of cyclin D1 in human pancreatic carcinoma is associated with poor prognosis. Cancer Res 1997, 57: $1634-1637$

17. Ogino S, Kawasaki T, Kirkner GJ, Yamaji T, Loda M, Fuchs CS: Loss of nuclear p27 (CDKN1B/KIP1) in colorectal cancer is 
correlated with microsatellite instability and CIMP. Mod Pathol 2007, 20:15-22

18. Sasaki S, Yamamoto H, Kaneto H, Ozeki I, Adachi Y, Takagi H, Matsumoto T, Itoh H, Nagakawa T, Miyakawa H, Muraoka S, Fujinaga A, Suga T, Satoh M, Itoh F, Endo T, Imai K: Differential roles of alterations of p53, p16, and SMAD4 expression in the progression of intraductal papillary-mucinous tumors of the pancreas. Oncol Rep 2003, 10:21-25

19. Al-Aynati MM, Radulovich N, Ho J, Tsao MS: Overexpression of G1-S cyclins and cyclin-dependent kinases during multistage human pancreatic duct cell carcinogenesis. Clin Cancer Res 2004, 10: 6598-6605

20. Rozenblum E, Schutte M, Goggins M, Hahn SA, Panzer S, Zahurak M, Goodman SN, Sohn TA, Hruban RH, Yeo CJ, Kern SE: Tumor-suppressive pathways in pancreatic carcinoma. Cancer Res 1997, 57:1731-1734

21. Lu JW, Lin YM, Chang JG, Yeh KT, Chen RM, Tsai JJ, Su WW, Hu RM: Clinical implications of deregulated CDK4 and Cyclin D1 expression in patients with human hepatocellular carcinoma. Med Oncol 2013, 30:379

22. Kang YK, Kim WH, Jang JJ: Expression of G1-S modulators (p53, p16, p27, cyclin D1, Rb) and Smad4/Dpc4 in intrahepatic cholangiocarcinoma. Hum Pathol 2002, 33:877-883

23. Hui AM, Li X, Shi YZ, Takayama T, Torzilli G, Makuuchi M: Cyclin D1 overexpression is a critical event in gallbladder carcinogenesis and independently predicts decreased survival for patients with gallbladder carcinoma. Clin Cancer Res 2000, 6:4272-4277

24. Ito Y, Matsuura N, Sakon M, Miyoshi E, Noda K, Takeda T, Umeshita K, Nagano H, Nakamori S, Dono K, Tsujimoto M, Nakahara M, Nakao K, Taniguchi N, Monden M: Expression and prognostic roles of the G1-S modulators in hepatocellular carcinoma: p27 independently predicts the recurrence. Hepatology 1999, 30: 90-99

25. Borg A, Sandberg T, Nilsson K, Johannsson O, Klinker M, Masback A, Westerdahl J, Olsson H, Ingvar C: High frequency of multiple melanomas and breast and pancreas carcinomas in CDKN2A mutation-positive melanoma families. J Natl Cancer Inst 2000, 92: $1260-1266$

26. Matsumoto M, Furihata M, Ishikawa T, Ohtsuki Y, Ogoshi S: Comparison of deregulated expression of cyclin D1 and cyclin E with that of cyclin-dependent kinase 4 (CDK4) and CDK2 in human oesophageal squamous cell carcinoma. Br J Cancer 1999, 80: 256-261

27. Takano Y, Kato Y, van Diest PJ, Masuda M, Mitomi H, Okayasu I: Cyclin D2 overexpression and lack of p27 correlate positively and cyclin $\mathrm{E}$ inversely with a poor prognosis in gastric cancer cases. Am J Pathol 2000, 156:585-594

28. Mori M, Mimori K, Shiraishi T, Tanaka S, Ueo H, Sugimachi K, Akiyoshi T: p27 expression and gastric carcinoma (letter to the editor). Nat Med 1997, 3:593

29. Gomyo Y, Ikeda M, Osaki M, Tatebe S, Tsujitani S, Ikeguchi M, Kaibara N, Ito H: Expression of p21 (waf1/cip1/sdi1), but not p53 protein, is a factor in the survival of patients with advanced gastric carcinoma. Cancer 1997, 79:2067-2072

30. Bleeker WA, Hayes VM, Karrenbeld A, Hofstra RM, Hermans J, Buys CC, Plukker JT: Impact of KRAS and TP53 mutations on survival in patients with left- and right-sided Dukes' C colon cancer. Am J Gastroenterol 2000, 95:2953-2957

31. Bondi J, Husdal A, Bukholm G, Nesland JM, Bakka A, Bukholm IR Expression and gene amplification of primary (A, B1, D1, D3, and E) and secondary $(\mathrm{C}$ and $\mathrm{H})$ cyclins in colon adenocarcinomas and correlation with patient outcome. J Clin Pathol 2005, 58:509-514

32. Cole AM, Myant K, Reed KR, Ridgway RA, Athineos D, Van den Brink GR, Muncan V, Clevers H, Clarke AR, Sicinski P, Sansom OJ: Cyclin D2-cyclin-dependent kinase 4/6 is required for efficient proliferation and tumorigenesis following Apc loss. Cancer Res 2010, 70:8149-8158
33. Zhao P, Hu YC, Talbot IC: Expressing patterns of p16 and CDK4 correlated to prognosis in colorectal carcinoma. World J Gastroenterol 2003, 9:2202-2206

34. Ogino S, Nosho K, Irahara N, Kure S, Shima K, Baba Y, Toyoda S, Chen L, Giovannucci EL, Meyerhardt JA, Fuchs CS: A cohort study of cyclin D1 expression and prognosis in 602 colon cancer cases. Clin Cancer Res 2009, 15:4431-4438

35. Wangefjord S, Manjer J, Gaber A, Nodin B, Eberhard J, Jirstrom K: Cyclin D1 expression in colorectal cancer is a favorable prognostic factor in men but not in women in a prospective, population-based cohort study. Biol Sex Differ 2011, 2:10

36. Zhao J, Li L, Wei S, Gao Y, Chen Y, Wang G, Wu Z: Clinicopathological and prognostic role of cyclin D1 in esophageal squamous cell carcinoma: a meta-analysis. Dis Esophagus 2012, 25:520-526

37. Zeestraten EC, Maak M, Shibayama M, Schuster T, Nitsche U, Matsushima T, Nakayama S, Gohda K, Friess H, van de Velde CJ, Ishihara H, Rosenberg R, Kuppen PJ, Janssen KP: Specific activity of cyclin-dependent kinase I is a new potential predictor of tumour recurrence in stage II colon cancer. Br J Cancer 2012, 106: $133-140$

38. Loda M, Cukor B, Tam SW, Lavin P, Fiorentino M, Draetta GF, Jessup JM, Pagano M: Increased proteasome-dependent degradation of the cyclin-dependent kinase inhibitor p27 in aggressive colorectal carcinomas. Nat Med 1997, 3:231-234

39. Nosho K, Kawasaki T, Chan AT, Ohnishi M, Suemoto Y, Kirkner GJ, Fuchs CS, Ogino S: Cyclin D1 is frequently overexpressed in microsatellite unstable colorectal cancer, independent of CpG island methylator phenotype. Histopathology 2008, 53:588-598

40. Wangefjord S, Brandstedt J, Lindquist KE, Nodin B, Jirstrom K, Eberhard J: Associations of beta-catenin alterations and MSI screening status with expression of key cell cycle regulating proteins and survival from colorectal cancer. Diagn Pathol 2013, 8:10

41. Ismail A, Bandla S, Reveiller M, Toia L, Zhou Z, Gooding WE, Kalatskaya I, Stein L, D’Souza M, Litle VR, Peters JH, Pennathur A, Luketich JD, Godfrey TE: Early G(1) cyclin-dependent kinases as prognostic markers and potential therapeutic targets in esophageal adenocarcinoma. Clin Cancer Res 2011, 17:4513-4522

42. Pishvaian MJ, Yang S, El Zouhairi M, Wu C, Mishra L, Avantaggiati M: Synergistic anti-cancer activity of the CDK4/6 inhibitor PD-0332991 in combination with 5-fluorouracil-based chemotherapy in human colon cancer cells. Cancer Res 2010, 70(Suppl): Abstract 5047

43. Singh SP, Lipman J, Goldman H, Ellis FH Jr, Aizenman L, Cangi MG, Signoretti S, Chiaur DS, Pagano M, Loda M: Loss or altered subcellular localization of p27 in Barrett's associated adenocarcinoma. Cancer Res 1998, 58:1730-1735

44. Biankin AV, Kench JG, Morey AL, Lee CS, Biankin SA, Head DR, Hugh TB, Henshall SM, Sutherland RL: Overexpression of p21(WAF1/CIP1) is an early event in the development of pancreatic intraepithelial neoplasia. Cancer Res 2001, 61:8830-8837

45. Ichikawa K, Imura J, Kawamata H, Takeda J, Fujimori T: Downregulated p16 expression predicts poor prognosis in patients with extrahepatic biliary tract carcinomas. Int J Oncol 2002, 20:453-461

46. Grady WM, Willis JE, Trobridge P, Romero-Gallo J, Munoz N, Olechnowicz J, Ferguson K, Gautam S, Markowitz SD: Proliferation and Cdk4 expression in microsatellite unstable colon cancers with TGFBR2 mutations. Int J Cancer 2006, 118:600-608

47. Caldas C, Hahn SA, da Costa LT, Redston MS, Schutte M, Seymour AB, Weinstein CL, Hruban RH, Yeo CJ, Kern SE: Frequent somatic mutations and homozygous deletions of the p16 (MTS1) gene in pancreatic adenocarcinoma. Nat Genet 1994, 8:27-32

48. Herman JG, Merlo A, Mao L, Lapidus RG, Issa JP, Davidson NE, Sidransky D, Baylin SB: Inactivation of the CDKN2/p16/MTS1 gene is frequently associated with aberrant DNA methylation in all common human cancers. Cancer Res 1995, 55:4525-4530

49. Toncheva D, Petrova D, Tzenova V, Dimova I, Yankova R, Yordanov V, Damjanov D, Todorov T, Zaharieva B: Tissue 
microarray analysis of cyclin D1 gene amplification and gain in colorectal carcinomas. Tumour Biol 2004, 25:157-160

50. Fry DW, Harvey PJ, Keller PR, Elliott WL, Meade M, Trachet E, Albassam M, Zheng X, Leopold WR, Pryer NK, Toogood PL: Specific inhibition of cyclin-dependent kinase 4/6 by PD 0332991 and associated antitumor activity in human tumor xenografts. Mol Cancer Ther 2004, 3:1427-1438

51. Rivadeneira DB, Mayhew CN, Thangavel C, Sotillo E, Reed CA, Grana X, Knudsen ES: Proliferative suppression by CDK4/6 inhibition: complex function of the retinoblastoma pathway in liver tissue and hepatoma cells. Gastroenterology 2010, 138:1920-1930

52. Lane ME, Yu B, Rice A, Lipson KE, Liang C, Sun L, Tang C, McMahon G, Pestell RG, Wadler S: A novel cdk2-selective inhibitor, SU9516, induces apoptosis in colon carcinoma cells. Cancer Res 2001, 61:6170-6177

53. Wang S, Ayyub E, Lamphere L: Evaluation of selective biomarkers of the broad spectrum CDK inhibitor: RGB-286199. Cancer Res 2005, 65:1045

54. Takagi K, Sowa Y, Cevik OM, Nakanishi R, Sakai T: CDK inhibitor enhances the sensitivity to 5 -fluorouracil in colorectal cancer cells. Int J Oncol 2008, 32:1105-1110

55. Ziemke E, Dosch J, Settigar A, Wan S, Welling T, Hardiman K, Sebolt-Leopold J: Dual targeting of CDK4 and MEK as a combination treatment strategy for metastatic colorectal cancer. Cancer Res 2014, 74(Suppl): Abstract 4541

56. Pishvaian MJ, Upadhyay G, Yao Z, Kim Y, Said A, Mendelson J, Kitisin K, Volpe E, Blake T, Kim S, Baek H, Anthony M, Bibhuti RRP, Mishra L: CDK4 is an important target for hepatocellular cancer with inactivation of TGF-beta signaling through Smad and ELF. Cancer Res 2008, May 1, 68:2583 [Abstract 2583]

57. Raju U, Ariga H, Koto M, Lu X, Pickett J, Valdecanas D, Mason KA, Milas L: Improvement of esophageal adenocarcinoma cell and xenograft responses to radiation by targeting cyclin-dependent kinases. Radiother Oncol 2006, 80:185-191

58. Wainberg ZA, Yufa A, Anghel A, Rogers AM, Manivong T, Adhami S, Hamidi H, Conklin D, Finn RS, Slamon DJ: Expression of p16 in colon cancer and cyclin D1 in gastric cancer predicts response to CDK 4/6 inhibition in vitro. Clin Cancer Res 2013, 19:5320-5328

59. Jung CP, Motwani MV, Schwartz GK: Flavopiridol increases sensitization to gemcitabine in human gastrointestinal cancer cell lines and correlates with down-regulation of ribonucleotide reductase M2 subunit. Clin Cancer Res 2001, 7:2527-2536

60. Elliott MJ, Farmer MR, Atienza C Jr, Stilwell A, Dong YB, Yang HL, Wong SL, McMasters KM: E2F-1 gene therapy induces apoptosis and increases chemosensitivity in human pancreatic carcinoma cells. Tumour Biol 2002, 23:76-86

61. Iseki H, Ko TC, Xue XY, Seapan A, Townsend CM Jr: A novel strategy for inhibiting growth of human pancreatic cancer cells by blocking cyclin-dependent kinase activity. J Gastrointest Surg 1998, $2: 36-43$

62. Bible KC, Kaufmann SH: Cytotoxic synergy between flavopiridol (NSC 649890, L86-8275) and various antineoplastic agents: the importance of sequence of administration. Cancer Res 1997, 57: $3375-3380$

63. Kim DM, Koo SY, Jeon K, Kim MH, Lee J, Hong CY, Jeong S: Rapid induction of apoptosis by combination of flavopiridol and tumor necrosis factor (TNF)-alpha or TNF-related apoptosis-inducing ligand in human cancer cell lines. Cancer Res 2003, 63:621-626

64. Motwani M, Delohery TM, Schwartz GK: Sequential dependent enhancement of caspase activation and apoptosis by flavopiridol on paclitaxel-treated human gastric and breast cancer cells. Clin Cancer Res 1999, 5:1876-1883

65. Shah MA, Kortmansky J, Motwani M, Drobnjak M, Gonen M, Yi S, Weyerbacher A, Cordon-Cardo C, Lefkowitz R, Brenner B, O’Reilly E, Saltz L, Tong W, Kelsen DP, Schwartz GK: A phase I clinical trial of the sequential combination of irinotecan followed by flavopiridol. Clin Cancer Res 2005, 11:3836-3845
66. Rathkopf D, Dickson MA, Feldman DR, Carvajal RD, Shah MA, Wu N, Lefkowitz R, Gonen M, Cane LM, Dials HJ, Winkelmann JL, Bosl GJ, Schwartz GK: Phase I study of flavopiridol with oxaliplatin and fluorouracil/leucovorin in advanced solid tumors. Clin Cancer Res 2009, 15:7405-7411

67. Meng RD, Carvajal RD, Tse AN, Shah MA, Dials HJ, Bruckner D, O'Reilly EM, Kelsen DP, Schwartz GK: A phase I clinical and pharmacokinetic study of flavopiridol administered concurrently with 5- fluorouracil, leucovorin, and oxaliplatin (FOLFOX) for advanced solid tumors 2006;24(18s):13515

68. Dickson MA, Shah MA, Rathkopf D, Tse A, Carvajal RD, Wu N, Lefkowitz RA, Gonen M, Cane LM, Dials HJ, Schwartz GK: A phase I clinical trial of FOLFIRI in combination with the pan-cyclindependent kinase (CDK) inhibitor flavopiridol. Cancer Chemother Pharmacol 2010, 66:1113-1121

69. Aklilu M, Kindler HL, Donehower RC, Mani S, Vokes EE: Phase II study of flavopiridol in patients with advanced colorectal cancer. Ann Oncol 2003, 14:1270-1273

70. Carvajal RD, Tse A, Shah MA, Lefkowitz RA, Gonen M, GilmanRosen L, Kortmansky J, Kelsen DP, Schwartz GK, O'Reilly EM: A phase II study of flavopiridol (Alvocidib) in combination with docetaxel in refractory, metastatic pancreatic cancer. Pancreatology 2009, 9:404-409

71. Schwartz GK, LoRusso PM, Dickson MA, Randolph SS, Shaik MN, Wilner KD, Courtney R, O'Dwyer PJ: Phase I study of PD 0332991, a cyclin-dependent kinase inhibitor, administered in 3-week cycles (Schedule 2/1). Br J Cancer 2011, 104:1862-1868

72. Flaherty KT, Lorusso PM, Demichele A, Abramson VG, Courtney R, Randolph SS, Shaik MN, Wilner KD, O'Dwyer PJ, Schwartz GK: Phase I, dose-escalation trial of the oral cyclin-dependent kinase $4 / 6$ inhibitor PD 0332991, administered using a 21-day schedule in patients with advanced cancer. Clin Cancer Res 2012, 18:568-576

73. Littman SJ, Knudsen ES, Witkiewicz A, Hyslop T, Lewis N, Pillai MV, Brus C, Mitchell EP: A phase II study of PD-0332991 in patients with advanced hepatocellular cancer. J Clin Oncol 2013, 31(Suppl): Abstract 321

74. Wade Goldman J, Gandhi L, Patnaik A, Rosen LS, Hilton JF, Papadopoulos KP, Tolaney SM, Beeram M, Rasco DW, Myrand SP, Beckmann RP, Kulanthaivel P, Frenzel M, Cronier D, Chan EM, Flaherty K, Wen PY, Tolcher AW, Shapiro G: Clinical activity of LY2835219, a novel cell cycle inhibitor selective for CDK4 and CDK6, in patients with non-small cell lung cancer. J Clin Oncol 2014, 32(Suppl): Abstract 8026

75. Infante JR, Shapiro G, Witteveen P, Gerecitano JF, Ribrag V, Chugh R, Issa I, Chakraborty A, Matano A, Zhao X, Parasuraman S, Cassier P: A phase I study of the single-agent CDK4/6 inhibitor LEE011 in pts with advanced solid tumors and lymphomas. J Clin Oncol 2014, 32(Suppl): Abstract 2528

76. Patnaik A, Rosen LS, Tolaney SM, Tolcher AW, Goldman JW, Gandhi L, Papadopoulos KP, Beeram M, Rasco DW, Myrand SP, Kulanthaivel P, Li L, Frenzel M, Cronier DM, Chan EM, Flaherty KT, Wen PY, Shapiro GI: Clinical activity of LY2835219, a novel cell cycle inhibitor selective for CDK4 and CDK6, in patients with metastatic breast cancer. J Clin Oncol 2014, 32(Suppl): Abstract 534

77. von Euw EM, Conklin D, Rong HM, Gong KW, Finn RS, Slamon DJ: Identification of markers of sensitivity and resistance to palbociclib (PD0332991) in melanoma. Cancer Res 2014, 74(Suppl): Abstract 1321

78. Konecny GE, Winterhoff B, Kolarova T, Qi J, Manivong K, Dering J, Yang G, Chalukya M, Wang HJ, Anderson L, Kalli KR, Finn RS, Ginther C, Jones S, Velculescu VE, Riehle D, Cliby WA, Randolph S, Koehler M, Hartmann LC, Slamon DJ: Expression of p16 and retinoblastoma determines response to CDK4/6 inhibition in ovarian cancer. Clin Cancer Res 2011, 17:1591-1602

79. Finn RS, Dering J, Conklin D, Kalous O, Cohen DJ, Desai AJ, Ginther C, Atefi M, Chen I, Fowst C, Los G, Slamon DJ: PD 0332991, a selective cyclin D kinase 4/6 inhibitor, preferentially inhibits proliferation of luminal estrogen receptor-positive human breast cancer cell lines in vitro. Breast Cancer Res 2009, 11:R77 
80. Grilley-Olson JE, Weiss GJ, Rajagopalan P, Henderson DA, Kornacker M, Govindan R: A dose-escalation phase I study of oral pan-CDK inhibitor BAY 1000394 in patients with advanced solid tumors: dose escalation with an intermittent 28 days on/14 days off schedule. J Clin Oncol 2012, 30(Supp): Abstract 3046

81. Bahleda R, Gazzah A, Varga A, Rajagopalan P, Henderson DA, Kornacker M, Soria JC: A first-in-human phase I study of oral panCDK inhibitor BAY 1000394 in patients with advanced solid tumors: dose escalation with an intermittent 3 days on $/ 4$ days off schedule. J Clin Oncol 2012, 30(Suppl): Abstract 3012

82. Takahashi I, Asano K, Kawamoto I, Tamaoki T, Nakano H: UCN-01 and UCN-02, new selective inhibitors of protein kinase C. I. Screening, producing organism and fermentation. J Antibiot (Tokyo) 1989, 42:564-570

83. Busby EC, Leistritz DF, Abraham RT, Karnitz LM, Sarkaria JN: The radiosensitizing agent 7-hydroxystaurosporine (UCN-01) inhibits the DNA damage checkpoint kinase hChk1. Cancer Res 2000, 60: 2108-2112

84. Kortmansky J, Shah MA, Kaubisch A, Weyerbacher A, Yi S, Tong W, Sowers R, Gonen M, O'Reilly E, Kemeny N, Ilson DI, Saltz LB, Maki RG, Kelsen DP, Schwartz GK: Phase I trial of the cyclin-dependent kinase inhibitor and protein kinase $\mathrm{C}$ inhibitor 7hydroxystaurosporine in combination with Fluorouracil in patients with advanced solid tumors. J Clin Oncol 2005, 23:1875-1884

85. Kondapaka SB, Zarnowski M, Yver DR, Sausville EA, Cushman SW: 7-hydroxystaurosporine (UCN-01) inhibition of Akt Thr308 but not Ser473 phosphorylation: a basis for decreased insulin-stimulated glucose transport. Clin Cancer Res 2004, 10:7192-7198

86. Tse AN, Rendahl KG, Sheikh T, Cheema H, Aardalen K, Embry M, Ma S, Moler EJ, Ni ZJ, Lopes de Menezes DE, Hibner B, Gesner TG, Schwartz GK: CHIR-124, a novel potent inhibitor of Chk1, potentiates the cytotoxicity of topoisomerase I poisons in vitro and in vivo. Clin Cancer Res 2007, 13:591-602

87. Solit DB, Zheng FF, Drobnjak M, Munster PN, Higgins B, Verbel D, Heller G, Tong W, Cordon-Cardo C, Agus DB, Scher HI, Rosen N: 17-Allylamino-17-demethoxygeldanamycin induces the degradation of androgen receptor and HER-2/neu and inhibits the growth of prostate cancer xenografts. Clin Cancer Res 2002, 8:986-993

88. El-Rayes BF, Gadgeel S, Shields AF, Manza S, Lorusso P, Philip PA: Phase I study of bryostatin 1 and gemcitabine. Clin Cancer Res 2006, 12:7059-7062

89. Philip PA, Rea D, Thavasu P, Carmichael J, Stuart NS, Rockett H, Talbot DC, Ganesan T, Pettit GR, Balkwill F: Phase I study of bryostatin 1: assessment of interleukin 6 and tumor necrosis factor alpha induction in vivo. The Cancer Research Campaign Phase I Committee. J Natl Cancer Inst 1993, 85:1812-1818

90. Clamp AR, Blackhall FH, Vasey P, Soukop M, Coleman R, Halbert G, Robson L, Jayson GC; Cancer Research UK Phase I/II Committee: A phase II trial of bryostatin-1 administered by weekly 24-hour infusion in recurrent epithelial ovarian carcinoma. Br J Cancer 2003, 89:1152-1154

91. Zonder JA, Shields AF, Zalupski M, Chaplen R, Heilbrun LK, Arlauskas P, Philip PA: A phase II trial of bryostatin 1 in the treatment of metastatic colorectal cancer. Clin Cancer Res 2001, 7:38-42

92. Le Tourneau C, Faivre S, Laurence V, Delbaldo C, Vera K, Girre V, Chiao J, Armour S, Frame S, Green SR, Gianella-Borradori A, Dieras V, Raymond E: Phase I evaluation of seliciclib (R-roscovitine), a novel oral cyclin-dependent kinase inhibitor, in patients with advanced malignancies. Eur J Cancer 2010, 46:3243-3250
93. Tong WG, Chen R, Plunkett W, Siegel D, Sinha R, Harvey RD, Badros AZ, Popplewell L, Coutre S, Fox JA, Mahadocon K, Chen T, Kegley P, Hoch U, Wierda WG: Phase I and pharmacologic study of SNS-032, a potent and selective Cdk2, 7, and 9 inhibitor, in patients with advanced chronic lymphocytic leukemia and multiple myeloma. J Clin Oncol 2010, 28:3015-3022

94. Martinez-Urbina MA, Zentella A, Vilchis-Reyes MA, Guzman A, Vargas O, Ramirez Apan MT, Ventura Gallegos JL, Diaz E: 6Substituted 2-(N-trifluoroacetylamino)imidazopyridines induce cell cycle arrest and apoptosis in SK-LU-1 human cancer cell line. Eur J Med Chem 2010, 45:1211-1219

95. Dickson MA, Tap WD, Keohan ML, D’Angelo SP, Gounder MM, Antonescu CR, Landa J, Qin LX, Rathbone DD, Condy MM, Ustoyev Y, Crago AM, Singer S, Schwartz GK: Phase II trial of the CDK4 inhibitor PD0332991 in patients with advanced CDK4amplified well-differentiated or dedifferentiated liposarcoma. J Clin Oncol 2013, 31:2024-2028

96. Finn RS, Boer K, Lang I, Parikh RJ, Patel R, Schmidt M, Hagenstad CT, Lim HJ, Pinter T, Amadori D, Chan D, Dichmann R, Kim ST, Randolph S, Slamon DJ, Crown JP: A randomized phase II study of PD 0332991, cyclin-dependent kinase (CDK) 4/6 inhibitor, in combination with letrozole for first-line treatment of patients with postmenopausal, estrogen receptor (ER)-positive, human epidermal growth factor receptor 2 (HER2)-negative advanced breast cancer. J Clin Oncol 2011, 29(Suppl): Abstract TPS100

97. Gopalan PK, Pinder MC, Chiappori A, Ivey AM, Godillo-Villegas A, Kaye FJ: A phase II clinical trial of CDK 4/6 inhibitor palbociblib (PD 0332991) in previously treated, advanced non-small cell lung cancer (NSCLC) patients with inactivated CDKN2A. J Clin Oncol 2014, 32(Suppl): Abstract 8077

98. Liu X, Ory V, Chapman S, Yuan H, Albanese C, Kallakury B, Timofeeva OA, Nealon C, Dakic A, Simic V, Haddad BR, Rhim JS, Dritschilo A, Riegel A, McBride A, Schlegel R: ROCK inhibitor and feeder cells induce the conditional reprogramming of epithelial cells. Am J Pathol 2012, 180:599-607

99. Palechor-Ceron N, Suprynowicz FA, Upadhyay G, Dakic A, Minas T, Simic V, Johnson M, Albanese C, Schlegel R, Liu X: Radiation induces diffusible feeder cell factor(s) that cooperate with ROCK inhibitor to conditionally reprogram and immortalize epithelial cells. Am J Pathol 2013, 183:1862-1870

100. Pollock CB, McDonough S, Wang VS, Lee H, Ringer L, Li X, Prandi C, Lee RJ, Feldman AS, Koltai H, Kapulnik Y, Rodriguez OC, Schlegel R, Albanese C, Yarden RI: Strigolactone analogues induce apoptosis through activation of p38 and the stress response pathway in cancer cell lines and in conditionally reprogrammed primary prostate cancer cells. Oncotarget 2014, 5:1683-1698

101. Yuan H, Myers S, Wang J, Zhou D, Woo JA, Kallakury B, Ju A, Bazylewicz M, Carter YM, Albanese C, Grant N, Shad A, Dritschilo A, Liu X, Schlegel R: Use of reprogrammed cells to identify therapy for respiratory papillomatosis. N Engl J Med 2012, 367:1220-1227

102. Ringer L, Sirajuddin P, Tricoli L, Waye S, Choudhry MU, Parasido E, Sivakumar A, Heckler M, Naeem A, Abdelgawad I, Liu X, Feldman AS, Lee RJ, Wu CL, Yenugonda V, Kallakury B, Dritschilo A, Lynch J, Schlegel R, Rodriguez O, Pestell RG, Avantaggiati ML, Albanese C: The induction of the p53 tumor suppressor protein bridges the apoptotic and autophagic signaling pathways to regulate cell death in prostate cancer cells. Oncotarget 2014, 5:10678-10691 